\title{
TOTAL FACTOR PRODUCTIVITY GROWTH IN CHINA'S CORN FARMING: AN APPLICATION OF GENERALIZED PRODUCTIVITY INDICATOR
}

\author{
Zhiyong NIU ${ }^{1}$, Yining ZHANG ${ }^{2}$, Tianxiang $\mathrm{LI}^{3}$, Tomas BALEŽENTIS®4, \\ Dalia ŠTREIMIKIENĖ(1) 5 , Zhiyang SHEN (1) 6* \\ ${ }^{1}$ Shanghai University of Finance and Economics, 200433 Shanghai, China \\ ${ }^{2}$ Agricultural University of Hebei, 061100 Cangzhou, China \\ ${ }^{3}$ College of Economics and Management, Nanjing Agricultural University, 210095 Nanjing, China \\ ${ }^{4,5}$ Lithuanian Centre for Social Sciences, 03220 Vilnius, Lithuania \\ ${ }^{6}$ School of Management and Economics, Beijing Institute of Technology, 100081 Beijing, China
}

Received 15 October 2020; accepted 01 April 2021

\begin{abstract}
Total factor productivity (TFP) growth measures usually focus on a certain direction of optimization and ignore the general setting encompassing the input and output orientations simultaneously. This paper uses the generalized Luenberger-Hicks-Moorsteen (LHM) TFP indicator which is additively complete and can be decomposed by three mutually exclusive elements. The input- and output-oriented analysis is undertaken in order to derive the generalized TFP measured. The paper uses the corn production data from 19 Chinese provinces over the period of 2004-2017. This research is important as China is the second largest corn producer in the world. The TFP growth was observed for Chinese corn farming the rate of $0.56 \%$ per year. The technological progress $(0.48 \%)$ was the major source of the TFP growth, whereas the importance of the technical efficiency change $(0.09 \%)$ and scale efficiency change $(-0.01 \%)$ was negligible.
\end{abstract}

Keywords: corn production, total factor productivity, Luenberger-Hicks-Moorsteen indicator, data envelopment analysis, efficiency change, technological progress.

JEL Classification: M41, C83, L20.

\section{Introduction}

China is the second largest maize producer in the world. In 2019, China's maize farming area was 41,284 thousand hectares and the harvest reached 260.77 million tons (National Bureau of Statistics of China, 2020; Ma et al., 2012; Wang et al., 2019). There has been a steep upward trend in China's agricultural output (and productivity) since the "reform and opening up" policy of 1978. However, maize production in China has recently faced subdued growth

${ }^{\star}$ Corresponding author. E-mail: zhiyang86@163.com

Copyright $\odot 2021$ The Author(s). Published by Vilnius Gediminas Technical University

This is an Open Access article distributed under the terms of the Creative Commons Attribution License (http://creativecommons. org/licenses/by/4.0/), which permits unrestricted use, distribution, and reproduction in any medium, provided the original author and source are credited. 
rates. Given the importance of China's agricultural production for the commodity markets and food security in general, it is important to discuss the major factors of the productivity growth in China's maize farming and possible policy measures for promotion thereof. The expansion of agricultural activities may affect the sustainability and face an increasing production risk. In this sense, the use of agrochemicals and pesticides should be taken into account.

Both the external (e.g., climate change) and internal (e.g., technological development) factors influence Chinese maize production. Since the implementation of the maize storage policy in 2008, the farming area of maize in China has increased substantially. However, maize supply exceeds the demand due to sluggish growth in domestic consumption. In 2016, the National Development and Reform Commission proposed to cancel the policy of temporary purchase and storage in several main maize producing provinces. In the midst of policy changes, decreasing relative yield and area sown, maize production efficiency is an important issue related to the future maize supply.

The use of agricultural inputs should also be improved in China. For instance, China produces $21 \%$ of the world's grain and consumes $35 \%$ of fertilizer inputs (National Bureau of Statistics of China, 2020). Excessive use of fertilizers and pesticides may eventually impact the efficiency and sustainability of the agricultural production in China (such issues have been observed in other countries as well, e.g., Mohamed \& Nageye, 2020). Mechanization of China's agriculture and the increasing greenhouse gas emissions also cast a negative impact on the environment. Therefore, factors inputs related to the environmental pressures should be taken into account (see, e.g., Popescu et al., 2015, for a discussion on industrial sustainability). This would allow assessing the potential of maize production from the perspective of sustainable development.

The analysis of total factor productivity (TFP) growth relies on estimation of a production frontier (or another representation of the productive technology). The estimation can follow either parametric or non-parametric vein (with semi-parametric approach in between). The parametric estimation aims at statistical inference of the parameters of the pre-specified production function. The non-parametric estimation does not involve a predefined function form. As a result, one avoids the risk of mistakenly defining the functional form at the cost of loss of the statistical inference. Much research applied nonparametric approach to analyze agricultural performance in terms of efficiency or productivity (Blancard et al., 2011; Ilyas et al., 2020; Nastis et al., 2019; Skevas \& Cabrera, 2020). The non-parametric efficiency measures can be used to construct productivity indices and indicators (Chambers, 2002; Blancard \& Hoarau, 2011; O’Donnell, 2012). Briec and Kerstens (2004) proposed the Luenberger-HicksMoorsteen (LHM) TFP indicator, which can be regarded as a "complete" TFP indicator that can be decomposed into contributions related to the input use and the output production. This study also follows the non-parametric approach and applies the LHM TFP indicator.

The earlier studies on the agricultural TFP growth in China applied different methods. Tian and Yu (2012) carried out a meta-analysis and suggested a 2.03\% annual TFP growth for China's agriculture considering the data from 1950-2008. The productivity growth of China's maize farming was assessed by Wang et al. (2017). They applied the Malmquist index and found the average annual loss of maize farming productivity of 1.3\% during 2004-2014 at province level. Kim and Chavas (2003) investigated the linkages between technological change and production risk in relation to maize. They argued that technological progress can 
reduce the risk premium that varies over time and space, but they did not consider the TFP of the maize sector. Key (2019) used the US census data from 1982 to 2012 and developed a framework for estimating the maize aggregate productivity growth from cohort data. Still, there have been no studies to apply the generalized measure of TFP growth for China's crop farming. The use of the LHM TFP indicator would, thus, render more reliable estimated of the TFDP growth in this context.

This study uses the generalized LHM TFP indicator to measure the productivity growth from different perspectives (Shen et al., 2019). The paper uses the maize production data of 19 Chinese provinces over the period of 2004-2017. The generalized LHM indicator decomposes additively. Indeed, the earlier literature adopted Malmquist index or Luenberger indicator (Wang et al., 2017; Li \& Zhang, 2013; Song et al., 2016) to calculate the TFP growth. However, both of those measures are incomplete and lead to a biased estimates of TFP growth (O'Donnell, 2012; Kerstens et al., 2018). According to Kerstens et al. (2018), LHM is additively complete and can accurately reflect the TFP growth. Also, this research embarks on the generalized decomposition of TFP growth, whereas the existing literature (Wang et al., 2017; Key, 2019) followed either input- or outputoriented decomposition. By using the primal approach, this paper also avoids the price data to decompose the TFP growth in the maize farming.

The remainder of the paper is organized as follows. Section 2 reviews the policy development in the Chinese maize plating sector from 2004 onwards. Section 3 discusses the calculations behind the generalized LHM indicator and its decomposition. Section 4 presents the data used. Section 5 discusses the TFP growth and its sources for China's maize sector over the period of 2004-2017.

\section{Policy measures for the Chinese maize farming sector}

In 2004, the "No. 1 Central Document" of the Central Committee of the Communist Party of China proposed deepening the reform of the grain circulation system and establishing a direct subsidy policy for farmers, which effectively protected the interests of farmers growing grain (State Council of the CPC Central Committee, 2004). "The Decision of the Central Committee of the National People's Congress on Abolishing the Regulation of the People's Republic of China on Agriculture Tax" was introduced in 2005, which abolished agricultural taxes and granted direct subsidies to farmers. At the same time, the grain price also appeared to display an overall upward trend and the grain farming unit area net profit increased (Central Committee of the National People's Congress, 2005). Since then, in order to protect the interests of grain farmers, steadily develop grain production, and improve the minimum purchase price policy for key grain varieties, the Chinese government has started to implement incentive policies for major grain-producing provinces. Amongst them, the policy of the Chinese government concerning the maize farming industry mainly includes five aspects. Appendix presents the summary of the policy measures taken in the Chinese maize sector.

"Several Opinions of the State Council of the CPC Central Committee on Promoting the Stable Development of Agriculture and the Sustainable Increase of Farmers' Income in 2009" (State Council of the CPC Central Committee, 2009) put forward that direct subsidies to grain-growing farmers should continue to be increased, and the subsidy dynamic adjustment 
mechanism should be improved to strengthen the monitoring of agricultural production cost and income. For the purpose of increasing grain production and farmers' income, the state has implemented the system of temporary storage of maize in the three northeastern provinces and the Inner Mongolia Autonomous Region. The system is meant to support the participation of enterprises in the collection and storage of maize, as well as an improved auction mechanism for the national collection and storage of agricultural products. This policy has completely manipulated the price of agricultural production and the ability of farmers to increase income. The policy has also protected the interests of farmers and increased farmers' enthusiasm to plant maize. Maintaining this kind of market stability has played an important role.

To promote scientific research on risk control and yield gains, the General Office of the Ministry of Agriculture in China issued the "National Green Prevention and Control Guidelines for Maize Locust" (General Office of the Ministry of Agriculture in China, 2010), proposing measures for prevention-based and integrated control to further realize key green technologies, integration of popularization and application, and optimization of comprehensive benefits.

"Several Opinions on Accelerating the Advancement of Agricultural Science and Technology Innovation and Continuously Enhancing the Supply Guarantee Ability of Agricultural Products", (State Council of the CPC Central Committee, 2012) issued by the Central Committee of the Communist Party of China and the State Council, pointed out that the fundamental path for the sustainable and stable development of agriculture lies in science and technology. These factors accelerate mechanized agriculture, concentrate efforts on solving outstanding problems such as the mechanical harvesting of maize, rapeseed, sugar cane, and cotton, and vigorously develop equipment such as agricultural facilities, animal husbandry, and aquatic products. "Several Opinions of the State Council of the CPC Central Committee on Comprehensively Deepening Rural Reform and Accelerating Agricultural Modernization" (State Council of the CPC Central Committee, 2014a) further stressed the need to speed up the development of modern seed industries and mechanized agriculture.

"Several Opinions of the State Council of the CPC Central Committee on Deepening the Reform in Rural Areas in an All Round Way and Accelerating the Development of Agricultural Modernization" (State Council of the CPC Central Committee, 2014b) proposed that the policy of temporary collection and storage of maize, rapeseed, and sugar should be continued. According to the policy, it increases the proportion of premium subsidies for major grain crop insurance at the central and provincial levels, and gradually reduces or abolishes county-level premium subsidies for major grain-producing counties. The insurance coverage and risk guarantee level of the three major grain varieties, paddy, wheat, and maize, have been improved continuously. This provides a guarantee for the maize farming industry against the risks of agricultural production.

"Several Opinions of the State Council of the CPC Central Committee on implementation of the New Concepts on the Development and Acceleration of the Agricultural Modernization for Realization of the Moderate Prosperity in All Respects" (State Council of the CPC Central Committee, 2016) launched the farming structure adjustment plan, proposing to appropriately reduce the farming of maize in non-advantageous areas to optimize the agricultural production structure and regional distribution. In the same year, the state abolished the temporary policy of maize collection and storage, and adjusted it to promote the reform of the system of maize collection and storage in accordance with the principle of market pricing, 
and set up a system of subsidies for maize producers. This policy improved the price formation mechanism of maize, increased the enthusiasm of farmers, activated the maize circulation market, and effectively reduced maize inventory. In 2017, the Ministry of Agriculture issued the "Several Opinions on Deepening the Supply-Side Structural Reform in Agriculture" (Ministry of Agriculture in China, 2017), which further proposed to accelerate the restructuring of the farming industry with a focus on maize. It vigorously developed the foundations for highquality raw materials and the production of special varieties for processing. The government supports major grain-producing areas in developing the processing of grain, especially maize, and vigorously developing the agricultural products' processing industry.

\section{Methods}

This paper relies on the non-parametric approach to quantify the TFP growth in Chinese maize farming. Therefore, this section briefly describes the major concepts and models used in the research. First, the productive technology and the corresponding efficiency measures (distance functions) are described. Then, the measurement and decomposition of the TFP growth on the basis of the LHM indicator is discussed. Finally, the relevant linear programming problems are defined.

In order to measure the TFP growth and inter-provincial differences of maize production possibilities in China, one needs to establish the production frontier using the input and output of maize producing provinces. In general, the underlying production technology can be defined in terms of the production possibility set, that maps the feasible input and output vectors (quantities). Given the assumption of a multiple-input, multiple-output production technology, each decision making unit (DMU) produces outputs $\left(y \in R^{Q}\right)$ by utilizing inputs $\left(x \in R^{P}\right)$. Therefore, the feasible production plans comprise the production possibility set:

$$
T=\left\{(x, y) \in R_{+}^{P+Q}: x \text { can } \operatorname{produce}(y)\right\} .
$$

In our case, the province-level production plans are considered. In this research, the following economic assumptions are imposed: closedness, convexity, variable returns to scale, and free disposability (Shephard, 1970; Fare \& Primont, 1995; Hackman, 2007). These axioms are modelled by introducing the constraints in the corresponding linear programs.

The production technology is defined by identifying the limits for input and output quantities that correspond to the "benchmark" performance. The differences between the actual production plans and the benchmark ones can be quantifies by applying the distance functions. The conventional Shephard distance function defined the proportional changes (scaling) of the input or output vector. A more general measure is the Directional Distance Function (DDF) which can adjust the elements of the input and output vectors. This measure is flexible as the direction vector can be defined by the decision makers according to their objective for each observation independently (Blancard et al., 2006). The DDF $D\left(x, y ; g_{x}, g_{y}\right)$ can be defined as:

$$
D\left(x, y ; g_{x}, g_{y}\right)=\max \left\{\beta, \delta \in \mathfrak{R}_{+}:\left(x-\beta g_{x}, y+\delta g_{y}\right) \in T\right\},
$$

where $\left(g_{x}, g_{y}\right) \geq 0$ is the direction vector simultaneous input and output variation in the direction vector, and $\beta$ and $\delta$ are the inefficiency scores related to the input contraction and 
output expansion, respectively. Therefore, $D($.) characterizes the underlying technology by measuring the maximum possible increase in outputs and decrease in inputs (depending on the directional vector).

Shen et al. (2019) proposed the general decomposition of Luenberger-Hicks-Moorsteen (LHM) TFP indicator that relies on the directional distance functions. This indicator is applied to calculate the TFP growth of maize farming in 19 provinces of China. The LHM TFP indicator aggregated the distance functions that are measured with respect to the frontier of a certain time period in the input or output direction. While the other variables are fixed, those associated with non-zero elements of the directional vector are changed given their values in periods $t$ and $t+1$. As the generalized indicator is applied, one needs to consider TFP growth with periods $t$ and $t+1$ considered as the base ones:

$$
\begin{aligned}
\operatorname{TFP}^{t}= & {\left[D^{t}\left(x_{k}^{t}, y_{k}^{t} ; 0, g_{y}^{t}\right)-D^{t}\left(x_{k}^{t}, y_{k}^{t+1} ; 0, g_{y}^{t+1}\right)\right]-} \\
& {\left[D^{t}\left(x_{k}^{t+1}, y_{k}^{t} ; g_{x}^{t+1}, 0\right)-D^{t}\left(x_{k}^{t}, y_{k}^{t} ; g_{x}^{t}, 0\right)\right] ; } \\
\operatorname{TFP} P^{t+1}= & {\left[D^{t+1}\left(x_{k}^{t+1}, y_{k}^{t} ; 0, g_{y}^{t}\right)-D^{t+1}\left(x_{k}^{t+1}, y_{k}^{t+1} ; 0, g_{y}^{t+1}\right)\right]-} \\
& {\left[D^{t+1}\left(x_{k}^{t+1}, y_{k}^{t+1} ; g_{x}^{t+1}, 0\right)-D^{t+1}\left(x_{k}^{t}, y_{k}^{t+1} ; g_{x}^{t}, 0\right)\right], }
\end{aligned}
$$

where TFP $P^{t}$ and $T F P^{t+1}$ are the LHM indicators measuring productivity growth with respect to frontiers $t$ and $t+1$ respectively. The arithmetic mean of the two indicators given in Eq. (3) is the generalized LHM TFP growth indicator:

$$
T F P^{t, t+1}=\frac{1}{2}\left(T F P^{t}+T F P^{t+1}\right) .
$$

Note that, following O'Donnell (2012), Diewert and Fox $(2014,2017)$ and Ang and Kerstens (2017), the above LHM TFP indicator decomposes into components that can be related to the input change and output change. As it is the case with most of the productivity indicators, one can decompose the lHM TFP indicator in order to isolate the changes in the distance to the frontier (i.e., efficiency change) and the frontier shift (i.e., technical change). In addition, the curvature of the frontier varies with input and output quantities. This is captured by the scale efficiency change. Thus, the LHM TFP indicator decomposes as:

$$
T F P^{t, t+1}=T E C^{t, t+1}+T P^{t, t+1}+S E C^{t, t+1},
$$

where $\mathrm{TEC}^{t, t+1}$ is the contribution of movement towards the production frontier (technical efficiency change), $T P^{t, t+1}$ captures the shift of the technological frontier (technical progress), and $S E C^{t, t+1}$ shows the impact the scale efficiency change. The values of the terms of Eq. (5) above unity indicate gains in the TFP, whereas those below unity are related to loss in the TFP.

To calculate the LHM TFP indicator, one is required to apply input and output DDFs and, thus, does not rely on a single orientation. However, it can be decomposed by exploiting either input or output DDFs for the calculation of the three terms on the right-hand-side of Eq. (5). The major advantage related to the use of the generalized measures of the TFP growth is that they do not require restrictive assumptions regarding the orientations of the 
analysis (i.e., input or output orientation). Instead, the terms of Eq. (5) are calculated for each orientation independently and aggregated by taking the arithmetic average as the LHM indicator follows the additive structure.

The input- or output-oriented calculations for the LHM TFP indicator consider the changes in the corresponding part of the production plan. TEC, TP, and SEC can be further decomposed into corresponding elements, according to output and input orientation. For instance, TEC can be decomposed into $T E C_{\text {output }}^{t, t+1}$ and $T E C_{\text {input }}^{t, t+1}$, by taking different directions which are defined by exploiting the DDFs as follows:

$$
\begin{aligned}
& \text { TEC } C^{t, t+1}=\frac{1}{2}\left(T E C_{\text {Output }}^{t, t+1}+T E C_{\text {Input }}^{t, t+1}\right)= \\
& \frac{1}{2}\left\{\begin{array}{l}
{\left[D^{t}\left(x_{k}^{t}, y_{k}^{t} ; 0, g_{y}^{t}\right)-D^{t+1}\left(x_{k}^{t+1}, y_{k}^{t+1} ; 0, g_{y}^{t+1}\right)\right]} \\
+\left[D^{t}\left(x_{k}^{t}, y_{k}^{t} ; g_{x}^{t} 0\right)-D^{t+1}\left(x_{k}^{t+1}, y_{k}^{t+1} ; g_{x}^{t+1}, 0\right)\right]
\end{array}\right\} .
\end{aligned}
$$

TP decomposes in a more complicated manner as the distances between the frontiers are measures in two directions and based on the two base periods:

$$
\begin{aligned}
& T P^{t, t+1}=\frac{1}{2}\left(T P_{\text {Output }}^{t, t+1}+T P_{\text {Input }}^{t, t+1}\right)= \\
& \frac{1}{2}\left\{\begin{array}{l}
\frac{1}{2}\left(\begin{array}{l}
{\left[D^{t+1}\left(x_{k}^{t}, y_{k}^{t} ; 0, g_{y}^{t}\right)-D^{t}\left(x_{k}^{t}, y_{k}^{t} ; 0, g_{y}^{t}\right)\right]} \\
+\left[D^{t+1}\left(x_{k}^{t+1}, y_{k}^{t+1} ; 0, g_{y}^{t+1}\right)-D^{t}\left(x_{k}^{t+1}, y_{k}^{t+1} ; 0, g_{y}^{t+1}\right)\right]
\end{array}\right) \\
+\frac{1}{2}\left(\begin{array}{l}
{\left[D^{t+1}\left(x_{k}^{t}, y_{k}^{t} ; g_{x}^{t}, 0\right)-D^{t}\left(x_{k}^{t}, y_{k}^{t} ; g_{x}^{t}, 0\right)\right]} \\
+\left[D^{t+1}\left(x_{k}^{t+1}, y_{k}^{t+1} ; g_{x}^{t+1}, 0\right)-D^{t}\left(x_{k}^{t+1}, y_{k}^{t+1} ; g_{x}^{t+1}, 0\right)\right]
\end{array}\right)
\end{array}\right\} .
\end{aligned}
$$

The calculations of the SEC are the most complex as they involve both changes in the inputs and outputs across different base periods and production plans:

$$
\left.\begin{array}{l}
S^{t, t+1}=\frac{1}{2}\left(S_{E} C_{\text {Output }}^{t, t+1}+S E C_{\text {Input }}^{t, t+1}\right)= \\
\frac{1}{2}\left(\begin{array}{l}
{\left[\begin{array}{l}
\left.D^{t}\left(x_{k}^{t+1}, y_{k}^{t+1} ; 0, g_{y}^{t+1}\right)-D^{t}\left(x_{k}^{t}, y_{k}^{t+1} ; 0, g_{y}^{t+1}\right)\right] \\
-\left[D^{t}\left(x_{k}^{t+1}, y_{k}^{t} ; g_{x}^{t+1}, 0\right)-D^{t}\left(x_{k}^{t}, y_{k}^{t} ; g_{x}^{t}, 0\right)\right] \\
+\left[D^{t+1}\left(x_{k}^{t+1}, y_{k}^{t} ; 0, g_{y}^{t}\right)-D^{t+1}\left(x_{k}^{t}, y_{k}^{t} ; 0, g_{y}^{t}\right)\right] \\
-\left[D^{t+1}\left(x_{k}^{t+1}, y_{k}^{t+1} ; g_{x}^{t+1}, 0\right)-D^{t+1}\left(x_{k}^{t}, y_{k}^{t+1} ; g_{x}^{t}, 0\right)\right]
\end{array}\right)} \\
\left(\begin{array}{l}
{\left[D^{t}\left(x_{k}^{t+1}, y_{k}^{t+1} ; g_{x}^{t+1} 0\right)-D^{t}\left(x_{k}^{t}, y_{k}^{t+1} ; g_{x}^{t+1}, 0\right)\right]} \\
-\left[D^{t}\left(x_{k}^{t+1}, y_{k}^{t} ; 0, g_{y}^{t+1}\right)-D^{t}\left(x_{k}^{t}, y_{k}^{t} ; 0, g_{y}^{t}\right)\right] \\
+\left[D^{t+1}\left(x_{k}^{t+1}, y_{k}^{t} ; g_{x}^{t}, 0\right)-D^{t+1}\left(x_{k}^{t}, y_{k}^{t} ; g_{x}^{t}, 0\right)\right] \\
-\left[D^{t+1}\left(x_{k}^{t+1}, y_{k}^{t+1} ; 0, g_{y}^{t+1}\right)-D^{t+1}\left(x_{k}^{t}, y_{k}^{t+1} ; 0, g_{y}^{t}\right)\right.
\end{array}\right)
\end{array}\right)
\end{array}\right\} .
$$


The equations defining calculations of the terms of the LHM TFP indicator (Eqs (6)-(8)) are based on the DDFs. Thus it is necessary to describe the estimation of these functions. This paper resorts to the non-parametric approach. This approach does not need specifying a particular functional form for a representation of the technology while allowing for its flexibility. Thus, the linear programming problems are defined and solved for each instance mentioned in Eqs (6)-(8). In the sequel, the most general cases that can be adapted to the remaining cases in the aforementioned equations are presented. Let there be time indexes $(a, b, c) \in\{t, t+1\} \times\{t, t+1\} \times\{t, t+1\}$. For example, the output DDF $D^{a}\left(x_{k}^{b}, y_{k}^{c} ; 0, g_{y}^{c}\right)$ is calculated by maximizing the output at direction governed by $g_{y}$ :

$$
D^{a}\left(x_{k^{\prime}}^{b}, y_{k^{\prime}}^{c} ; 0, g_{y}^{c}\right)=\max \delta
$$

s.t.

$$
\begin{aligned}
& \sum_{k=1}^{K} \lambda_{k} x_{p k}^{a} \leq x_{p k^{\prime}}^{b}, p=1,2, \cdots, P ; \\
& \sum_{k=1}^{K} \lambda_{k} y_{q k}^{a} \geq y_{q k^{\prime}}^{c}+\delta g_{q}^{c}, q=1,2, \cdots, Q ; \\
& \sum_{k=1}^{K} \lambda_{k}=1 ; \\
& \lambda_{k} \geq 0, k=1,2, \ldots, K .
\end{aligned}
$$

In Eqs (9)-(10), the optimization is carried out with respect to a given production technology that is defined in apiece-wise linear manner with $\lambda_{k}$ serving as the weights of the observations (intensity variables). The inequality signs correspond to the free disposability assumption. The inefficiency scores $\delta$ and $\beta$ approach the value of zero in case the production is efficient and increase otherwise.

\section{Data}

The TFP growth of Chinese maize farming is calculated by exploiting the balanced panel data. The present study focuses on China's 19 provinces that are engaged in maize production. These provinces include Hebei, Shanxi, Inner Mongolia, Liaoning, Jilin, Heilongjiang, Jiangsu, Anhui, Shandong, Henan, Hubei, Chongqing, Sichuan, Guizhou, Yunnan, Shannxi, Gansu, Ningxia, and Xinjiang. The research spans over the years of 2004-2017. The data involved primarily including the output per unit area of maize production in different provinces, the quantity of various input factors, and the price index of the means of production. These 19 provinces contain all the major producers of maize in China and account for more than 90 percent of the country's total maize output. The data were collected from the "National Agricultural Product Cost - Revenue Data Compilation" and the "China Rural Statistical Yearbook" for 2005-2018.

This study uses one output and five inputs for describing the maize production activities across China's provinces. The output is the maize yield (kilograms per $\mathrm{mu}^{1}$ ). The five inputs

\footnotetext{
${ }^{1} \mathrm{~A} \mathrm{mu}$ is a unit of land measurement used in China. One mu is $1 / 15$ ha or $0.1647 \mathrm{acres}$, so $6.42 \mathrm{mu}$ is equal to 0.428 ha or 1.058 acres.
} 
included are labor, machinery, fertilizer, seed, and other factors of production expressed in per mu terms. Labor input is expressed by the number of employed persons per mu. Machinery input is included in the model as the weighted sum of per mu machinery operation cost, fuel and power cost, maintenance and repair cost, and fixed assets depreciation. ${ }^{2}$ Fertilizer input enters the model as the amount of fertilizer (in kilograms) per mu. Seed is measured by the amount of used seed (in kilograms) per mu. Other costs are the residual cost value after deducting labor cost, machinery input, fertilizer input, and seed input from the total production cost (yuan per mu). In order to ensure the comparability of the monetary variables, the data are deflated to the price level of 2003. Table 1 gives the main descriptive statistics for the inputs and output used in the study.

The use of the input and output variables normalized by the land area implies certain adjustments in regards to the interpretation of the results. Basically, the intensive form of the production function is considered. Indeed, the scale efficiency (change) becomes "intensity" efficiency (change) as the input and output intensities rather than levels are considered. In case the input intensity is related to the input productivity (output per unit of input) in a non-linear fashion, one can observe changes in the curvature of the intensive production function. The corresponding effects on TFP growth are then captured by the SEC term as defined in Eq. (8).

The stylized facts in Table 1 already provide some conclusions in regards to the TFP growth in maize farming in China. The yield grew at $1.49 \%$ per year on average. This figure was lower than the growth rates observed for two inputs, namely fertilizers ( $2 \%$ per year) and machinery $(9.56 \%$ per year). Therefore, the direction of the TFP growth is uncertain and depends on the cost shares of the inputs. The use of labor and seeds (per mu) declined by $3.97 \%$ per year and $2.94 \%$ per year respectively. Other costs showed an increase of $0.96 \%$ per year. The labor use in China's crop farming has been obviously adjusting to the economic conditions rendered by the emergence of high-productivity economic sectors that mostly operate in the urban regions. The increasing use of machinery and fertilizers indicates adoption of the advanced farming practices that may further boost yields and, eventually, TFP of the crop farming in China.

Table 1. Data description and annual growth rates of inputs and outputs over 2004-2017

\begin{tabular}{|l|l|c|c|c|c|c|}
\hline & \multicolumn{1}{|c|}{ Variable } & Max & Min & Mean & S.D. & Annual growth rate \\
\hline \multirow{5}{*}{ Inputs } & Labor $($ days $/ \mathrm{mu})$ & 20.90 & 2.46 & 8.80 & 4.02 & $-3.97 \%$ \\
\cline { 2 - 7 } & Seed $(\mathrm{kg} / \mathrm{mu})$ & 4.60 & 1.24 & 2.39 & 0.57 & $-2.94 \%$ \\
\cline { 2 - 7 } & Fertilizer $(\mathrm{kg} / \mathrm{mu})$ & 33.97 & 12.82 & 23.12 & 4.20 & $2.00 \%$ \\
\cline { 2 - 7 } & Machinery $(\mathrm{yuan} / \mathrm{mu})$ & 198.55 & 8.63 & 62.93 & 34.42 & $9.56 \%$ \\
\cline { 2 - 7 } & Other costs $(\mathrm{yuan} / \mathrm{mu})$ & 121.29 & 11.19 & 36.77 & 22.10 & $0.96 \%$ \\
\hline \multirow{2}{*}{ Output } & Gross output $(\mathrm{kg} / \mathrm{mu})$ & 714.69 & 229.88 & 463.13 & 84.32 & $1.49 \%$ \\
\hline
\end{tabular}

\footnotetext{
$\overline{{ }^{2} \text { Machinery input per }} \mathrm{mu}=$ machinery operation fee per $\mathrm{mu}+$ irrigation fee per $\mathrm{mu}+$ fuel and power fee per mu + maintenance and repair fee per $m u+2 / 3 *$ fixed assets depreciation per mu.
} 


\section{Results}

Table 2 presents the TFP growth rates estimated by the LHM TFP indicator. The TFP growth is further attributed to the TEC, TP and SEC terms that, in turn, are measured in input and output directions. The results show that, on average, China's maize production TFP grew by $0.56 \%$ over the period of 2004-2017. As a result, the cumulative growth of $14 \%$ was achieved during 2004-2017. In general, the TFP of maize production in China followed a steep upward trend during 2004-2008 and a slightly negative afterwards. Specifically, the cumulative TFP growth of maize production increased from $7 \%$ in 2007 to $20 \%$ in 2008 . There may be two reasons for this increase. One was the lagging effect caused by the complete abolition of the agricultural tax system in 2006. The other reason was the introduction of direct subsidies for maize production in 2006. As a result, agricultural insurance premium subsidies were increased in 2007 and the total amount of the subsidies reached an all-time high of 102.8 billion yuan.

Table 2. Annual average national growth rates of the TFP indicator and its decomposition (2004-2017)

\begin{tabular}{|c|c|c|c|c|c|c|c|}
\hline \multirow{2}{*}{ Year } & \multirow{2}{*}{ TFP } & \multicolumn{2}{|c|}{ TEC } & \multicolumn{2}{c|}{ TP } & \multicolumn{2}{c|}{ SEC } \\
\cline { 3 - 8 } & & Output & Input & Output & Input & Output & Input \\
\hline 2004 & 0.0000 & 0.0000 & 0.0000 & 0.0000 & 0.0000 & 0.0000 & 0.0000 \\
\hline 2005 & 0.0773 & -0.0011 & 0.0082 & 0.0191 & 0.0500 & 0.0207 & -0.0196 \\
\hline 2006 & 0.0893 & -0.0201 & 0.0007 & 0.0268 & 0.0588 & 0.0379 & -0.0149 \\
\hline 2007 & 0.0744 & -0.0013 & 0.0099 & 0.0161 & 0.0338 & 0.0225 & -0.0065 \\
\hline 2008 & 0.2013 & 0.0135 & 0.0178 & 0.0401 & 0.0954 & 0.0470 & -0.0126 \\
\hline 2009 & 0.1193 & 0.0022 & 0.0018 & 0.0205 & 0.0528 & 0.0369 & 0.0051 \\
\hline 2010 & 0.1399 & 0.0041 & 0.0111 & 0.0361 & 0.0604 & 0.0297 & -0.0016 \\
\hline 2011 & 0.1285 & -0.0021 & 0.0107 & 0.0539 & 0.0804 & 0.0124 & -0.0268 \\
\hline 2012 & 0.1712 & 0.0029 & 0.0151 & 0.0587 & 0.0874 & 0.0240 & -0.0169 \\
\hline 2013 & 0.1293 & 0.0096 & 0.0173 & 0.0399 & 0.0653 & 0.0151 & -0.0180 \\
\hline 2014 & 0.1334 & 0.0050 & 0.0108 & 0.0367 & 0.0577 & 0.0250 & -0.0017 \\
\hline 2015 & 0.1069 & -0.0004 & 0.0093 & 0.0302 & 0.0428 & 0.0236 & 0.0013 \\
\hline 2016 & 0.1085 & 0.0042 & 0.0051 & 0.0259 & 0.0596 & 0.0241 & -0.0105 \\
\hline 2017 & 0.1409 & -0.0012 & 0.0067 & 0.0432 & 0.0865 & 0.0285 & -0.0228 \\
\hline $\begin{array}{l}\text { Average } \\
\text { annual } \\
\text { growth rate }\end{array}$ & $0.56 \%$ & $0.05 \%$ & $0.04 \%$ & $0.21 \%$ & $0.27 \%$ & $0.02 \%$ & $-0.03 \%$ \\
\hline Contribution & $100 \%$ & $8.93 \%$ & $7.14 \%$ & $37.50 \%$ & $48.21 \%$ & $3.57 \%$ & $-5.36 \%$ \\
\hline
\end{tabular}

The highest contribution by the TP term indicates that the aforementioned sector-wide measures induced the outward shift of the production frontier (compared to the point of origin). As it was expected, the effect of the TEC is relatively low given the limited sample size and high dimensionality of the input/output vector. Thus, the model mainly identified the TFP growth related to the changes in the position and shape of the production frontier for China's maize-producing provinces. 
The increasing input intensity is corroborated by the patterns of the TFP growth related to the SEC and TEC. Indeed, the input-oriented TEC positively contributed to the TFP growth, whereas the input-oriented SEC indicated a decline in the TFP. The opposite pattern is observed for the output-oriented TEC and SEC measures. this indicates that the observations moved along the production frontier and departed from the CRS frontier in the input direction, yet became closer to the CRS frontier in regards to the output direction. These trends would have been masked in the generalized indicator had not been applied.

The average annual growth of TEC, TP, and SEC are $0.09 \%, 0.48 \%$, and $-0.01 \%$, respectively. Looking at the relative contribution of these effects, these factors contributed to the TFP growth by $16.39 \%, 85.68 \%$, and $-2.07 \%$. The declining contribution by the SEC component of TFP growth suggests that China's maize farming does not always use the inputs up to the maximum possible extent (i.e., decreasing marginal products are observed). Still, this effect is not a decisive one. As it was already said, the TP contributed positively to TFP. Figure 1 gives the dynamics of the TFP growth along with decomposition thereof for the maize farming in China. Our estimates of productivity change remain steady from 2008. TP showed the highest cumulative effect in comparison to TEC and SEC. Therefore, TFP growth of the maize production industry in China is mainly driven by the overall movement of the production frontier as represented by the TP. Period-wise, the annual growth rate of TEC was negative (-0.0194) in 2006. At the same time, the SEC showed a turning point in 2011 after experiencing higher average annual growth rate of SEC during 2005-2011. After that, in 2011 (0.0144) and in 2013 (0.0029) there was negative growth in SEC. The years after 2013 indicated average annual growth rates recovered yet not reaching the highest values observed for 2009.

Although the change of technical efficiency shows an increasing trend during the period under analysis, the annual growth rate and its contribution to TFP growth of the maize production industry are relatively low. Thus, efficiency change does not appear as the main driving factor for the growth of TFP. In contrast, the maize production industry saw significant technological progress during 2004-2017, which is the main driving factor for TFP growth. The scale efficiency change indicates China's maize sector has not gained TFP from approach-

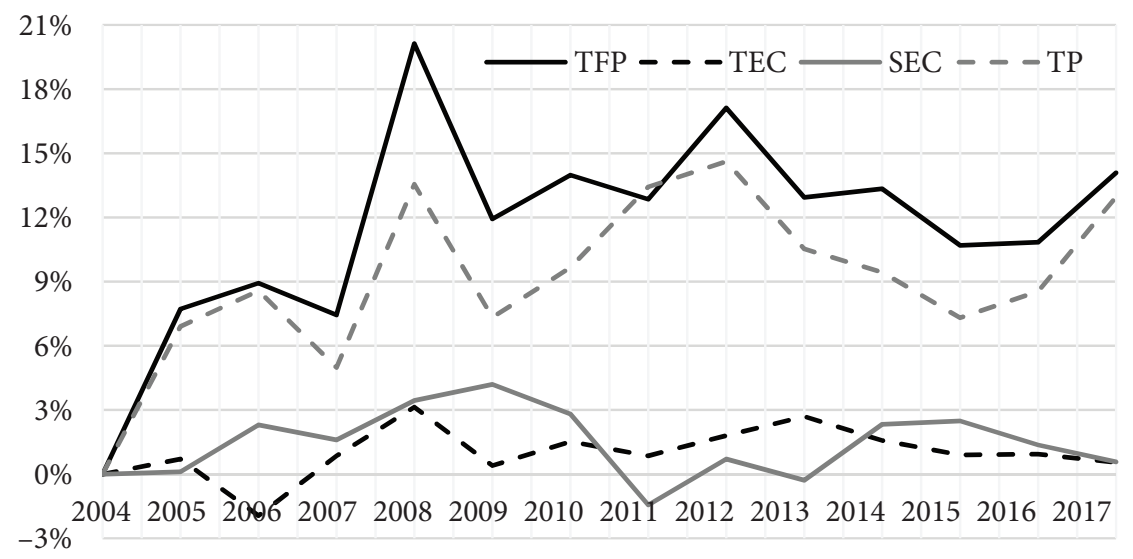

Figure 1. Cumulative TFP and its components 
ing reasonable production scale. The scale efficiency change presents a negative growth trend, especially from the point of investment orientation. The size of the sample period of maize production in the main provinces of China reveals that in most years, efficiency is negative. The period covered also indicates that the maize production concentrated in the major producing provinces of China can still be optimized.

As shown in Table 3, the TFP growth occurred at different rates across the 19 provinces. The maximum rate of $4.43 \%$ per year was observed for Jilin, whereas the minimum one of $-5.00 \%$ was observed for Ningxia. Jilin and Yunnan showed the highest TFP gains yet their sources were different. The TFP growth in Jilin was based on TP, whereas SEC was the most important for Yunnan. The case of Yunnan can be taken as an example for the lagging provinces. TP appeared as an important source of the TFP growth in a number of provinces, e.g., Shanxi, Jilin, Hubei, and Inner Mongolia. In general, there is a substantial variation in the magnitude and direction of the SEC component. Indeed, the negative contribution of SEC was observed for eight of the 19 provinces. In our setting, this indicates that these provinces moved to the region of less intensive farming and different curvature of the production frontier than it was observed for the most optimal scale size.

Table 3. Annual average provincial growth rates of the TFP indicator and its decomposition (20042017)

\begin{tabular}{|l|c|c|c|c|}
\hline \multicolumn{1}{|c|}{ Province } & TFP & TEC & SEC & TP \\
\hline Hebei & $-1.00 \%$ & $0.83 \%$ & $0.20 \%$ & $-2.03 \%$ \\
\hline Shanxi & $1.99 \%$ & $0.25 \%$ & $-2.01 \%$ & $3.75 \%$ \\
\hline Inner Mongolia & $2.27 \%$ & $0.59 \%$ & $-0.08 \%$ & $1.76 \%$ \\
\hline Liaoning & $1.32 \%$ & $-0.04 \%$ & $0.07 \%$ & $1.30 \%$ \\
\hline Jilin & $4.43 \%$ & $0.33 \%$ & $-2.11 \%$ & $6.21 \%$ \\
\hline Heilongjiang & $1.71 \%$ & $0.00 \%$ & $0.68 \%$ & $1.03 \%$ \\
\hline Jiangsu & $2.98 \%$ & $-0.33 \%$ & $3.28 \%$ & $0.03 \%$ \\
\hline Anhui & $-0.44 \%$ & $0.00 \%$ & $1.06 \%$ & $-1.49 \%$ \\
\hline Shandong & $0.32 \%$ & $-0.71 \%$ & $0.03 \%$ & $1.00 \%$ \\
\hline Henan & $-1.20 \%$ & $-0.12 \%$ & $0.32 \%$ & $-1.40 \%$ \\
\hline Hubei & $0.64 \%$ & $-1.23 \%$ & $-0.26 \%$ & $2.14 \%$ \\
\hline Chongqing & $-2.97 \%$ & $0.00 \%$ & $-1.55 \%$ & $-1.42 \%$ \\
\hline Sichuan & $1.02 \%$ & $0.93 \%$ & $-0.46 \%$ & $0.55 \%$ \\
\hline Guizhou & $1.84 \%$ & $0.68 \%$ & $2.48 \%$ & $-1.32 \%$ \\
\hline Yunnan & $2.91 \%$ & $0.78 \%$ & $1.93 \%$ & $0.21 \%$ \\
\hline Shaanxi & $0.46 \%$ & $-0.03 \%$ & $0.76 \%$ & $-0.26 \%$ \\
\hline Gansu & $1.52 \%$ & $-0.11 \%$ & $0.72 \%$ & $0.91 \%$ \\
\hline Ningxia & $-5.00 \%$ & $-0.07 \%$ & $-3.97 \%$ & $-0.96 \%$ \\
\hline Xinjiang & $-2.24 \%$ & $0.00 \%$ & $-1.29 \%$ & $-0.94 \%$ \\
\hline
\end{tabular}

However, the average annual rate of change in the TFP of six provinces was negative, including Hebei $(-1.00 \%)$, Anhui $(-0.44 \%)$, Henan (-1.20\%), Chongqing (-2.97\%), Ningxia 
$(-5.00 \%)$, and Xinjiang $(-2.24 \%)$. In most of these provinces, the negative rate of TFP growth was driven by the TP term. For Henan, the major agricultural province in China, the TP component $(-1.40 \%)$ accounts for almost all of its TFP decline.

\section{Discussion}

Zhang and $\mathrm{Hu}$ (2018) argued that maize farming in China has faced particularly severe effects of the climate change, especially in the Northeast area. There may be three reasons for the technological regress. First, the lack of technological innovations did not allow for the utilization of production potential. Second, limitations related to the natural conditions and industrial development level in these provinces may have also rendered a decline in the production frontier. Third, farmers in less developed regions are often engaged in part-time employment which further adds to insufficient input use and technological innovation.

The demand for maize will continue to increase in China both for increasing food demand and energy use (Yang et al., 2009). In the future, the China's maize farming requires improvements in sustainability and productivity. Both intensive farming practices and improved managerial frameworks may improve the performance of the sector (Ely et al., 2016). $\mathrm{Xu}$ et al. (2015) stressed the need for improved practices of nutrient management in China's maize sector so as to address the yield gap. The social dimension of the farming business also requires attention (Stanciu et al., 2019). As regards China, the rural-urban migration is likely to intensify the social problems related to agricultural business in general.

The results of this paper confirmed the presence of variation in the TFP growth across the provinces of China. Some of the major maize-growing provinces showed a decline in the TFP (e.g., Hebei and Henan). Therefore, this study may provide guidance in identifying the most relevant policy actions and directions thereof.

\section{Conclusions}

This paper applied the generalized Luenberger-Hicks-Moorsteen total factor productivity (TFP) indicator for Chinese maize production sector. The use of the generalized measures allowed for taking into account the productivity growth along input and output directions. The province-level data for 2004-2017 were used for the analysis.

The results show that the annual growth rate of TFP in maize production was $0.56 \%$ during 2004-2017. The major driving force was technological progress with annual contribution of $0.48 \%$. Thus, the country-wide innovation has appeared as the major factor behind the growth in TFP of the maize production. Further innovation spillover needs to be ensured in order to boost the income of farmers and improve food security. Scale efficiency change has a negative effect on TFP growth, which means that farming intensity in China's crop sector did not ensure movement towards the most productive scale size (in terms of input use and output production per land area). In addition, this study found that the growth rate of TFP was different between provinces of China. For example, Jilin, Hebei, and Henan are the major areas of maize production located in the Northeast China. However, Jilin has a positive value and Hebei and Henan have nega- 
tive values. The spatial inequality in regards to the TFP growth can be addressed by introducing support measures.

This paper considered the aggregate data to measure the TFP growth in China's maize farming. The data did not include the environmental pressures. The future research on the China's maize sector performance can be extended into a number of ways. The micro-level data could be applied to supplement the results of the aggregate-level analysis. The environmental production technology could be invoked in order to take the undesirable outputs into account and assess the environmental performance. The econometric techniques can be applied to perform the statistical inference.

\section{Acknowledgements}

Shen Z. appreciates the financial support from Beijing Institute of Technology Research Fund Program for Young Scholars. Li T. gratefully thanks the financial support from the National Science Foundation of China (Project No. 71934005, 71803085 and 71773051). Support by PAPD of Jiangsu Higher Education Institutions, Jiangsu Center for Food Security Studies, and Funds for the Central Universities (Project No. SKCX2017002 and SKYZ2020004) is also acknowledged.

\section{Author contributions}

Z.N., Y.Z. and Z.S.: Writing-original draft; Z.S. Methodology; T.L.: Data; T.B., D.S.: Formal analysis, Investigation, Software; T.L., T.B., D.S. and Z.S.: Writing-review \& editing, Validation. Z.N. and Z.S.: Project administration.

\section{References}

Ang, F., \& Kerstens, P. J. (2017). Decomposing the Luenberger-Hicks-Moorsteen total factor productivity indicator: An application to U.S. agriculture. European Journal of Operational Research, 260(1), 359-375. https://doi.org/10.1016/j.ejor.2016.12.015

Blancard, S., Boussemart, J.-P., \& Leleu, H. (2011). Measuring potential gains from specialization under non-convex technologies. Journal of the Operational Research Society, 62(10), 1871-1880.

https://doi.org/10.1057/jors.2010.148

Blancard, S., Boussemart, J.-P., Briec, W., \& Kerstens, K. (2006). Short- and long-run credit constraints in French agriculture: A directional distance function framework using expenditure-constrained profit functions. American Journal of Agricultural Economics, 88(2), 351-364. https://doi.org/10.1111/j.1467-8276.2006.00863.x

Blancard, S., \& Hoarau, J.-F. (2011). Optimizing the new formulation of the United Nations' human development index: An empirical view from data envelopment analysis. Economics Bulletin, 31(1), 989-1003. https://ideas.repec.org/a/ebl/ecbull/eb-10-00809.html

Briec, W., \& Kerstens, K. (2004). A Luenberger-Hicks-Moorsteen productivity indicator: Its relation to the Hicks-Moorsteen productivity indes and the Luenberger productivity indicator. Economic Theory, 23(4), 925-939. https://ideas.repec.org/a/spr/joecth/v23y2004i4p925-939.html

Central Committee of the Communist Party of China. (2004). No. 1 Central Document. Retrieved March 20, 2019, from http://www.gov.cn/test/2006-02/22/content_207415.htm 
Central Committee of the National People's Congress. (2005). The Decision of the Central Committee of the National People's Congress on Abolishing the Regulation of the People's Republic of China on Agriculture Tax. Retrieved March 12, 2019, from http://www.gov.cn/zhengce/2005-12/30/content_2602183.htm

Chambers, R. G. (2002). Exact non radial input, outputs, and productivity measurement. Economic Theory, 20, 751-65. https://doi.org/10.1007/s001990100231

Diewert, W. E., \& Fox, K. J. (2014). Reference technology sets, Free Disposal Hulls and productivity decompositions. Economics Letters, 122(2), 238-242. https://doi.org/10.1016/j.econlet.2013.11.026

Diewert, W. E., \& Fox, K. J. (2017). Decomposing productivity indexes into explanatory factors. European Journal of Operational Research, 256(1), 275-291. https://doi.org/10.1016/j.ejor.2016.05.043

Ely, A., Geall, S., \& Song, Y. (2016). Sustainable maize production and consumption in China: Practices and politics in transition. Journal of Cleaner Production, 134, 259-268.

https://doi.org/10.1016/j.jclepro.2015.12.001

Fare, R., \& Primont, D. (1995). Multi-output production and duality: Theory and applications. Springer Science \& Business Media. https://doi.org/10.1007/978-94-011-0651-1

General Office of the Ministry of Agriculture in China. (2010). National green prevention and control guidelines for Maize Locust. Retrieved June 12, 2019, from https://law.lawtime.cn/d676398681492. html

Hackman, S. T. (2007). Production economics: Integrating the microeconomic and engineering perspectives. Springer Science \& Business Media. https://books.google.lt/books/about/Production_Economics.html?id=gXC0H_R50e4C\&redir_esc=y

Ilyas, H. M. A., Safa, M., Bailey, A., Rauf, S., \& Khan, A. (2020). Energy efficiency outlook of New Zealand dairy farming systems: An application of data envelopment analysis (DEA) approach. Energies, 13(1), 251. https://doi.org/10.3390/en13010251

Kerstens, K., Shen, Z., \& Van de Woestyne, I. (2018). Comparing Luenberger and Luenberger-HicksMoorsteen productivity indicators: How well is total factor productivity approximated? International Journal of Production Economics, 195, 311-318. https://doi.org/10.1016/j.ijpe.2017.10.010

Key, N. (2019). Farm size and productivity growth in the United States Corn Belt. Food Policy, 84, 186-195. https://doi.org/10.1016/j.foodpol.2018.03.017

Kim, K., \& Chavas, J. P. (2003). Technological change and risk management: An application to the economics of corn production. Agricultural Economics, 29(2), 125-142. https://doi.org/10.1111/j.1574-0862.2003.tb00152.x

Li, Z., \& Zhang, H. (2013). Productivity growth in China’s agriculture during 1985-2010. Journal of Integrative Agriculture, 12(10), 1896-1904. https://doi.org/10.1016/S2095-3119(13)60598-5

Ma, Q., Yu, W.-T., Jiang, C.-M., Zhou, H., \& Xu, Y.-G. (2012). The influences of mineral fertilization and crop sequence on sustainability of maize production in northeastern China. Agriculture, Ecosystems and Environment, 158, 110-117. https://doi.org/10.1016/j.agee.2012.05.023

Ministry of Agriculture in China. (2017). Several opinions on deepening the supply-side structural reform in agriculture. Retrieved March 24, 2020, from http://www.moa.gov.cn/govpublic/BGT/201702/ t20170206_5468139.htm

Mohamed, A. A., \& Nageye, A. I. (2020). Measuring the effect of land degradation and environmental changes on agricultural production in Somalia with two structural breaks. Management of Environmental Quality, 32(2), 160-174. https://doi.org/10.1108/MEQ-02-2020-0032

Nastis, S. A., Bournaris, T., \& Karpouzos, D. (2019). Fuzzy data envelopment analysis of organic farms. Operational Research, 19(2), 571-584. https://doi.org/10.1007/s12351-017-0294-9

National Bureau of Statistics of China. (2020). http://www.stats.gov.cn/english/

O'Donnell, C. J. (2012). An aggregate quantity framework for measuring and decomposing productivity change. Journal of Productivity Analysis, 8(3), 255-272. https://doi.org/10.1007/s11123-012-0275-1 
Popescu, V. A., Popescu, G. N., \& Popescu, C. R. (2015). Competitiveness and sustainability - a modern economic approach to the industrial policy. Metalurgija, 54(2), 426-428.

https://core.ac.uk/download/pdf/25564878.pdf

Shen, Z., Balezentis, T., \& Ferrier, G. D. (2019). Agricultural productivity evolution in China: A generalized decomposition of the Luenberger-Hicks-Moorsteen productivity indicator. China Economic Review, 57, 101315. https://doi.org/10.1016/j.chieco.2019.101315

Shephard, R. W. (1970). Theory of cost and production functions. Princeton University Press. https://www.worldcat.org/title/theory-of-cost-and-production-functions/oclc/905862844

Skevas, T., \& Cabrera, V. E. (2020). Measuring farmers' dynamic technical and udder health management inefficiencies: The case of Wisconsin dairy farms. Journal of Dairy Science, 103(12), 1211712127. https://doi.org/10.3168/jds.2020-18656

Song, W., Han, Z., \& Deng, X. (2016). Changes in productivity, efficiency and technology of China's crop production under rural restructuring. Journal of Rural Studies, 47(B), 563-576.

https://doi.org/10.1016/j.jrurstud.2016.07.023

Stanciu, S., Virlanuta, F. O., Dinu, V., Zungun, D., \& Antohi, V. M. (2019), The perception of the social economy by agricultural producers in the North-East development region of Romania. Transformations in Business \& Economics, 18(2B (47B), 879-899.

State Council of the CPC Central Committee. (2004). Opinions of the Central Committee of the CPC and the State Council on the Several Policies for Promoting the Increase of Farmers' Income. Retrieved June 11, 2021, from http://www.gov.cn/test/2006-02/22/content_207415.htm

State Council of the CPC Central Committee. (2009). Several opinions of the state council of the CPC Central Committee on promoting the stable development of agriculture and the sustainable increase of farmers' income in 2009. Retrieved April 22, 2019, from http://www.gov.cn/gongbao/content/2009/ content_1220471.htm

State Council of the CPC Central Committee. (2012). Several opinions on accelerating the advancement of agricultural science and technology innovation and continuously enhancing the supply guarantee ability of agricultural products. Retrieved June 24, 2019, from http://www.moa.gov.cn/ztzl/yhwj/ zywj/201202/t20120215_2481552.htm

State Council of the CPC Central Committee. (2014a). Several opinions of the state council of the CPC Central Committee on Comprehensively deepening rural reform and accelerating agricultural modernization. Retrieved March 24, 2020, from http://www.gov.cn/gongbao/content/2014/content_2574736.htm

State Council of the CPC Central Committee. (2014b). Several opinions of the state council of the CPC Central Committee on deepening the reform in rural areas in an all round way and accelerating the development of agricultural modernization. Retrieved March 24, 2020, from http://www.gov.cn/ gongbao/content/2014/content_2574736.htm

State Council of the CPC Central Committee. (2016). Several opinions of the state council of the CPC Central Committee on implementation of the new concepts on the development and acceleration of the agricultural modernization for realize of the moderate prosperity in all respects. Retrieved March 24, 2020, from http://www.moa.gov.cn/ztzl/2016zyyhwj/2016zyyhwj/201601/t20160129_5002063.htm

Tian, X., \& Yu, X. (2012). The enigmas of TFP in China: A meta-analysis. China Economic Review, 23(2), 396-414. https://doi.org/10.1016/j.chieco.2012.02.007

Wang, H., Mu, Y., \& Hou, L. (2017). Research on temporal and spatial evolutions of environmental costs and total factor productivity of maize production in China. Journal of Natural Resources, 32(7), 1204-1216 (in Chinese).

Wang, Q., Gao, Z., Yuan, X., Wang, J., \& Wang, M. (2019). Comprehensive emergy evaluation and optimization of corn straw power generation system: A case study. Chinese Journal of Population Resources and Environment, 17(2), 135-144. https://doi.org/10.1080/10042857.2019.1610652 
Xu, X., Liu, X., He, P., Johnston, A. M., Zhao, S., Qiu, S., \& Zhou, W. (2015). Yield gap, indigenous nutrient supply and nutrient use efficiency for maize in China. PLoS One, 10(10), e0140767. https://doi.org/10.1371/journal.pone.0140767

Yang, Q., Chen, B., Ji, X., He, Y. F., \& Chen, G. Q. (2009). Exergetic evaluation of maize-ethanol production in China. Communications in Nonlinear Science and Numerical Simulation, 14(5), 2450-2461. https://doi.org/10.1016/j.cnsns.2007.08.011

Zhang, Q., \& Hu, Z. (2018). Assessment of drought during maize growing season in Northeast China. Theoretical and Applied Climatology, 133(3-4), 1315-1321.

https://doi.org/10.1007/s00704-018-2469-6

\section{APPENDIX}

Maize-related policies in China during 2004-2017

\begin{tabular}{|c|c|c|c|}
\hline $\begin{array}{l}\text { Year of } \\
\text { produc- } \\
\text { tion }\end{array}$ & $\begin{array}{l}\text { Production } \\
\text { Department }\end{array}$ & Policy name & Policy description \\
\hline \multirow[t]{2}{*}{2004} & $\begin{array}{l}\text { State Council } \\
\text { of China }\end{array}$ & $\begin{array}{l}\text { No. } 1 \text { Central } \\
\text { Document }\end{array}$ & Put forward the policy of grain subsidy. \\
\hline & $\begin{array}{l}\text { Ministry of } \\
\text { Agriculture } \\
\text { in China }\end{array}$ & $\begin{array}{l}\text { Opinions on } \\
\text { resuming the } \\
\text { development of } \\
\text { food production }\end{array}$ & Maize enters the range of premium seed subsidy. \\
\hline 2005 & $\begin{array}{l}\text { State Council } \\
\text { of China }\end{array}$ & $\begin{array}{l}\text { No. 1 Central } \\
\text { Document }\end{array}$ & $\begin{array}{l}\text { Implement high-quality grain industrial projects, } \\
\text { stabilize the area under cultivation of maize in the } \\
\text { main maize-producing areas, develop special-purpose } \\
\text { maize such as silage maize, and improve the deep } \\
\text { processing of maize. }\end{array}$ \\
\hline 2006 & $\begin{array}{l}\text { Ministry of } \\
\text { Agriculture } \\
\text { in China }\end{array}$ & $\begin{array}{l}\text { National Grain } \\
\text { Production } \\
\text { Development Plan } \\
(2006-2020)\end{array}$ & $\begin{array}{l}\text { Maize will be brought into the scope of the minimum } \\
\text { purchase price, and price standards conducive to } \\
\text { mobilizing farmers' enthusiasm will be formulated; } \\
\text { maize will be exported from the north to the south } \\
\text { to encourage moderate exports; and mechanical } \\
\text { equipment such as maize harvesting and Straw } \\
\text { returning to the field will be increased to raise the } \\
\text { level of agricultural mechanization equipment. }\end{array}$ \\
\hline \multirow[t]{2}{*}{2007} & $\begin{array}{l}\text { State Council } \\
\text { of China }\end{array}$ & $\begin{array}{l}\text { No. 1 Central } \\
\text { Document }\end{array}$ & $\begin{array}{l}\text { Continue to implement the minimum purchase price } \\
\text { policy for key areas and key grain varieties. }\end{array}$ \\
\hline & $\begin{array}{l}\text { State Council } \\
\text { of China }\end{array}$ & \begin{tabular}{l|} 
Guiding Opinions \\
on Promoting \\
the Healthy \\
Development \\
of Maize Deep \\
Processing \\
Industry
\end{tabular} & $\begin{array}{l}\text { To restrict the development of maize deep-processing } \\
\text { enterprises, especially the bio-energy industry using } \\
\text { maize as raw material, and to require all new and } \\
\text { expanded maize deep-processing projects to be } \\
\text { approved by the Investment Department in charge of } \\
\text { the State Council. }\end{array}$ \\
\hline
\end{tabular}


Continued Appendix

\begin{tabular}{|c|c|c|c|}
\hline $\begin{array}{l}\text { Year of } \\
\text { produc- } \\
\text { tion }\end{array}$ & $\begin{array}{l}\text { Production } \\
\text { Department }\end{array}$ & Policy name & Policy description \\
\hline & $\begin{array}{l}\text { Ministry of } \\
\text { Finance in } \\
\text { China }\end{array}$ & $\begin{array}{l}\text { Notice on } \\
\text { Cancellation of } \\
\text { Export Tax Rebate } \\
\text { for Wheat and } \\
\text { Other Raw Grain } \\
\text { and Flour Milling }\end{array}$ & $\begin{array}{l}\text { Starting from December 20,2007, the export tax } \\
\text { rebate for wheat, rice, rice, maize, soybean and other } \\
\text { raw grains and their flour products will be cancelled. }\end{array}$ \\
\hline & & $\begin{array}{l}\text { Temporary export } \\
\text { tariff on raw grain } \\
\text { and its flour }\end{array}$ & $\begin{array}{l}\text { From January } 1 \text { to December } 31,2008 \text {, the provisional } \\
\text { tax rate for the export of maize, rice, rice and } \\
\text { soybeans will be } 5 \text { per cent, while the provisional } \\
\text { tax rate for the export of maize flour, rice flour and } \\
\text { soybean flour will be } 10 \text { per cent. }\end{array}$ \\
\hline \multirow[t]{3}{*}{2008} & $\begin{array}{l}\text { State Council } \\
\text { of China }\end{array}$ & $\begin{array}{l}\text { No. } 1 \text { Central } \\
\text { Document }\end{array}$ & $\begin{array}{l}\text { Rationally guide the consumption of maize; support } \\
\text { the development of policy insurance for major grain } \\
\text { crops; and accelerate the promotion of Mechanization } \\
\text { for grain crops. }\end{array}$ \\
\hline & $\begin{array}{l}\text { State Council } \\
\text { of China }\end{array}$ & $\begin{array}{l}\text { Temporary Price- } \\
\text { Intervention } \\
\text { Measures on } \\
\text { Some Important } \\
\text { Commodities and } \\
\text { Services }\end{array}$ & $\begin{array}{l}\text { The policy of temporary collection and storage of } \\
\text { maize was officially implemented in three provinces } \\
\text { including Inner Mongolia, Heilongjiang, Jilin and } \\
\text { Liaoning. }\end{array}$ \\
\hline & $\begin{array}{l}\text { Ministry of } \\
\text { Agriculture } \\
\text { in China }\end{array}$ & $\begin{array}{l}\text { the Plan for the } \\
\text { Regional Layout } \\
\text { of national } \\
\text { advantageous } \\
\text { agricultural } \\
\text { products (2008- } \\
2015)\end{array}$ & $\begin{array}{l}\text { To construct three maize dominant areas in North, } \\
\text { Huang-huai-hai and Southwest China, and to play a } \\
\text { key role in satisfying domestic maize demand. }\end{array}$ \\
\hline \multirow[t]{2}{*}{2009} & \multirow[t]{2}{*}{$\begin{array}{l}\text { State Council } \\
\text { of China }\end{array}$} & $\begin{array}{l}\text { No. } 1 \text { Central } \\
\text { Document }\end{array}$ & $\begin{array}{l}\text { Increase subsidies for improved } \\
\text { varieties and raise the level of subsidies to achieve full } \\
\text { coverage of rice, wheat, maize and cotton. }\end{array}$ \\
\hline & & $\begin{array}{l}\text { Guiding } \\
\text { opinions on the } \\
\text { implementation of } \\
\text { the } 2009 \text { central } \\
\text { financial program } \\
\text { on subsidies for } \\
\text { improved varieties } \\
\text { of crops }\end{array}$ & $\begin{array}{l}\text { The maize subsidies for good varieties are directly } \\
\text { subsidized in cash, and the introduction of improved } \\
\text { varieties, voluntary seed purchase and direct } \\
\text { distribution are implemented. }\end{array}$ \\
\hline 2010 & $\begin{array}{l}\text { State Council } \\
\text { of China }\end{array}$ & $\begin{array}{l}\text { No. } 1 \text { Central } \\
\text { Document }\end{array}$ & $\begin{array}{l}\text { Timely adoption of maize, soybeans, rapeseed and } \\
\text { other temporary purchasing and storage policy. }\end{array}$ \\
\hline
\end{tabular}


Continued Appendix

\begin{tabular}{|c|c|c|c|}
\hline $\begin{array}{l}\text { Year of } \\
\text { produc- } \\
\text { tion }\end{array}$ & $\begin{array}{l}\text { Production } \\
\text { Department }\end{array}$ & Policy name & Policy description \\
\hline 2012 & $\begin{array}{l}\text { State Council } \\
\text { of China }\end{array}$ & $\begin{array}{l}\text { No. 1 Central } \\
\text { Document }\end{array}$ & $\begin{array}{l}\text { Timely start of temporary purchasing and storage of } \\
\text { maize, soybeans, rapeseed, cotton, sugar and other } \\
\text { items; push forward the water-saving and grain- } \\
\text { increasing actions in the four northeast provinces and } \\
\text { regions. }\end{array}$ \\
\hline 2013 & $\begin{array}{l}\text { State Council } \\
\text { of China }\end{array}$ & $\begin{array}{l}\text { No. } 1 \text { Central } \\
\text { Document }\end{array}$ & $\begin{array}{l}\text { Continue to implement the policy of temporary } \\
\text { maize purchase and storage, and increase the } \\
\text { coverage and risk assurance level of insurance for } \\
\text { maize and other grain varieties. }\end{array}$ \\
\hline 2014 & $\begin{array}{l}\text { Ministry of } \\
\text { Finance in } \\
\text { China }\end{array}$ & $\begin{array}{l}\text { Measures for the } \\
\text { administration of } \\
\text { temporary maize } \\
\text { purchase and } \\
\text { storage subsidies } \\
\text { in the countries } \\
\text { where the maize } \\
\text { processing } \\
\text { enterprises in } \\
\text { northeast China } \\
\text { are bidding for the } \\
\text { maize processing } \\
\text { enterprises }\end{array}$ & $\begin{array}{l}\text { Provincial (regional) meet certain qualification } \\
\text { conditions, have a certain processing capacity } \\
\text { of maize deep processing enterprises, within the } \\
\text { prescribed period of time bid for the processing } \\
\text { country temporary storage maize, more than a } \\
\text { certain amount of one-time subsidies. }\end{array}$ \\
\hline 2015 & $\begin{array}{l}\text { State Council } \\
\text { of China }\end{array}$ & $\begin{array}{l}\text { No. } 1 \text { Central } \\
\text { Document }\end{array}$ & $\begin{array}{l}\text { Adjust the structure of maize varieties, develop } \\
\text { animal husbandry, and support the farming of silage } \\
\text { maize and Alfalfa. }\end{array}$ \\
\hline \multirow[t]{3}{*}{2016} & $\begin{array}{l}\text { State Council } \\
\text { of China }\end{array}$ & $\begin{array}{l}\text { No. 1 Central } \\
\text { Document }\end{array}$ & $\begin{array}{l}\text { Press ahead with the reform of the system for } \\
\text { collecting and storing maize, establish a system of } \\
\text { subsidies for maize producers, introduce market } \\
\text { pricing for maize, and speed up the digestion of } \\
\text { maize and other stocks. }\end{array}$ \\
\hline & $\begin{array}{l}\text { Ministry of } \\
\text { Finance in } \\
\text { China }\end{array}$ & $\begin{array}{l}\text { Opinions on the } \\
\text { establishment of } \\
\text { maize producer } \\
\text { subsidy system }\end{array}$ & $\begin{array}{l}\text { To promote the reform of the maize harvest and } \\
\text { storage system, the state has set up a subsidy system } \\
\text { for maize producers, and has given subsidies to maize } \\
\text { producers in the northeast region, so as to promote } \\
\text { the basic balance. }\end{array}$ \\
\hline & $\begin{array}{l}\text { Department } \\
\text { of Crop } \\
\text { Farming } \\
\text { Adminis- } \\
\text { tration, } \\
\text { Ministry of } \\
\text { Agriculture }\end{array}$ & $\begin{array}{l}\text { National } \\
\text { Structural } \\
\text { Adjustment Plan } \\
\text { for Farming } \\
\text { Industry (2016- } \\
\text { 2020) }\end{array}$ & $\begin{array}{l}\text { Grain maize should be reduced, silage maize should } \\
\text { be expanded, fresh maize should be properly } \\
\text { developed to meet the needs of residents. }\end{array}$ \\
\hline
\end{tabular}


End of the Appendix

\begin{tabular}{|l|l|l|l|}
\hline $\begin{array}{c}\text { Year of } \\
\text { produc- } \\
\text { tion }\end{array}$ & $\begin{array}{l}\text { Production } \\
\text { Department }\end{array}$ & \multicolumn{1}{|c|}{ Policy name } & \multicolumn{1}{|c|}{ Policy description } \\
\hline & $\begin{array}{l}\text { State Council } \\
\text { of China }\end{array}$ & $\begin{array}{l}\text { Guiding Opinions } \\
\text { on Creating } \\
\text { Functional Areas } \\
\text { for Growing } \\
\text { Grains and } \\
\text { Conservation } \\
\text { Areas for Growing } \\
\text { Vital Agricultural } \\
\text { Products }\end{array}$ & $\begin{array}{l}\text { Focusing on Songnen Plain, Sanjiang Plain, Liaohe } \\
\text { Plain, huang-huai-hai region and Fen River and } \\
\text { Wei River River basins, 450 million mu of maize } \\
\text { production functional area has been delineated. }\end{array}$ \\
\cline { 2 - 4 } & $\begin{array}{l}\text { Ministry of } \\
\text { Finance in } \\
\text { China }\end{array}$ & $\begin{array}{l}\text { Taxation on } \\
\text { Resuming the } \\
\text { Export Tax } \\
\text { Refund Rate of } \\
\text { Maize Deep- } \\
\text { Processed } \\
\text { Products }\end{array}$ & $\begin{array}{l}\text { Since September 1, 2016 the export tax rebate rate of } \\
\text { value-added tax on maize starch, alcohol and other } \\
\text { deep-processed products will be restored to 13\%. }\end{array}$ \\
\hline 2017 & $\begin{array}{l}\text { State Council } \\
\text { of China }\end{array}$ & $\begin{array}{l}\text { No. 1 Central } \\
\text { Document }\end{array}$ & $\begin{array}{l}\text { Explore pilot projects for full cost insurance and } \\
\text { income insurance for maize and other grain crops, } \\
\text { and accelerate the establishment of a multi-level } \\
\text { agricultural insurance system. }\end{array}$ \\
\hline
\end{tabular}

